Corresponding Author:

V.V. Goman

vvg_electro@hotmail.com

Received: 5 March 2020

Accepted: 18 March 2020

Published: 8 April 2020

Publishing services provided by Knowledge E

(c) V.V. Goman. This article is distributed under the terms of the Creative Commons

Attribution License, which

permits unrestricted use and

redistribution provided that the

original author and source are credited.

Selection and Peer-review under the responsibility of the SEC 2019 Conference Committee.

\section{Prospects of Upgrade of the Main Drives of CNC Machine Tools Using Mechatronic Modules \\ V.V. Goman}

Ural Federal University named after the first Russian President B.N. Yeltsin, Nizhniy Tagil Technological institute Russia, 622000, Nizhniy Tagil, street Krasnogvardeyskaya, 59

\section{Abstract}

This article observes the principles of construction and operation of the belt drives with detached electric motor and the drives with motor spindle. It also describes the characteristics of the elements used in spindles. In choosing a spindle, one proceeds from the primary and secondary requirements for the machine tool: rotation speed, power output, hardness, workspace dimensions, design complexity, application area, option of repair and replacement, and cost. The article considers the advantages and disadvantages of the spindles with additional mechanic gears and the motor spindles. As an example, we compare variants of upgrade of the «16M30F3» machine tool's main drive. As a result, the following conclusions were made: motor spindle has more advantages than standard drive, but it is way more expensive and its repair is more difficult. Hence, this spindle type is only applicable to machine tools with high standards of quality and performance. Belt-driven spindle is special for easy repair and a wide range of technical specifications: one can choose multiple motor variants for one drive; again, it is much cheaper than motor spindle. However, final decision on spindle should concern the main requirements for the machine tool, workplace dimensions, application of the machine tool and, possibly, financial restrictions.

Keywords: CNC machine tool, motor spindle, mechatronics, machine building, electric drive, electric motor, motion control, built-in motor.

\section{Introduction}

Machine tool drive is an assembly of devices transferring motion from the energy source (motor) to the working tools of the machine tool with the option of controlling the speed of the working tools. Modern machine tools are usually equipped with individual drives. It means all motions of the machine tools are fed from separate electric motors [1]. Mechatronic modules are getting increasingly applicable in machine tool drives [2, 3].

One of the machine tool's motions is rotating the spindle with a workpiece. The main drive in machine tools has a number of features making it different from drive feeds: rated output of the electric motor has to be used in a wide range of rotational speeds; 
the drive works at a constant preset rotational speed for a long time; inertia moments are way greater than those of electric motors; positioning mode (servo mode) is used for a number of operations.

There are two types of drives responsible for spindle rotation:

1) Torque is transferred to the spindle from the electric motor (installed near or in the machine tool) via a belt or gear drive.

2) Torque is generated by an electric drive built in the spindle. It means that either the machine tool includes a spindle motor (electric spindle) or the spindle and the electric motor are connected through a coupling (direct drive).

The main belt drive includes a shaft on bearing supports; the shaft uses tool clamping/releasing systems. Power output and rotation are transferred to the spindle from an electric motor installed near the machine tool. Torque is transferred via a belt. Output, torque and speed of the working tool are determined by the electric motor properties, the transmission ratio of the belt and other mechanical gears.

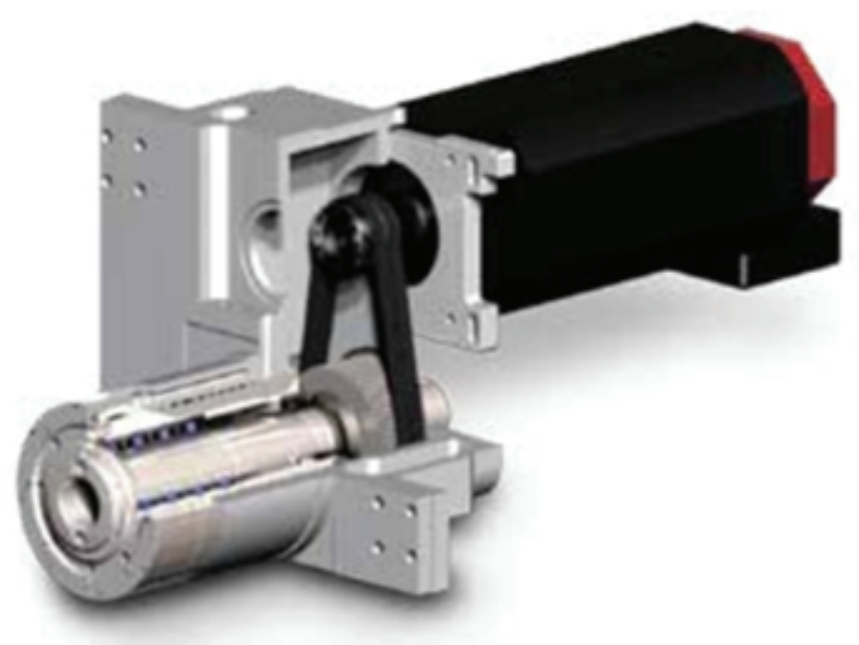

Figure 1: Example of belt-driven spindle with detached HX505 electric motor [4]

Most commonly used are drives with induction motor or synchronous motor which are installed together with speed gear boxes. In this way, the rated output of the motor is used across the entire range of the spindle rotational speeds. Application of electric motors with variable frequency drive (VSD) simplifies the design of speed gear box or allows to exclude it from the construction. Belt drive is used to ensure a convenient location of the electric motor or a certain transmission ratio in the drive.

Motor spindles include induction or synchronous electric motor [1]. Motor spindle consists of a casing with a stator containing a shaft with a rotor. Among the important units of motor spindles are high-speed bearings which provide high rotational speeds and dynamic load capacity. Such bearings are overload-sensitive and therefore subjected 


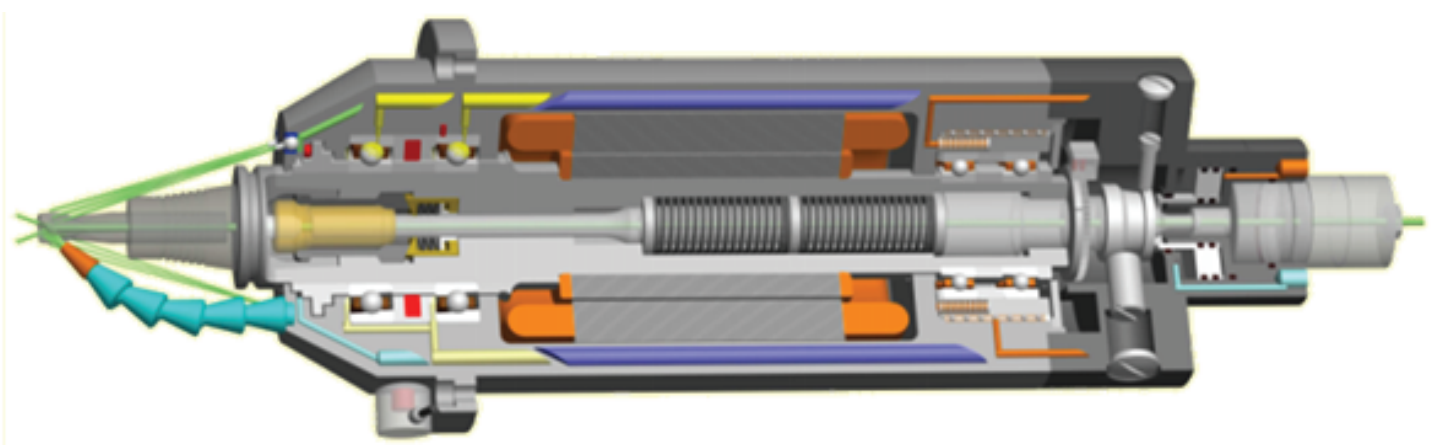

Figure 2: Example of motor spindle design [5]

to early wear and destruction of spindle supports. This problem is usually solved with ceramic bearing balls [1]. High-quality bearing supports improve the vibration resistance of a spindle which contributes to the results of the work. With all the load, temperature and speed ranges observed, such supports allow bearing to work for up to 40000 hours.

Among the possible solutions for integration of electric motor in the working tool is application of built-in torque motors (Fig. 3).

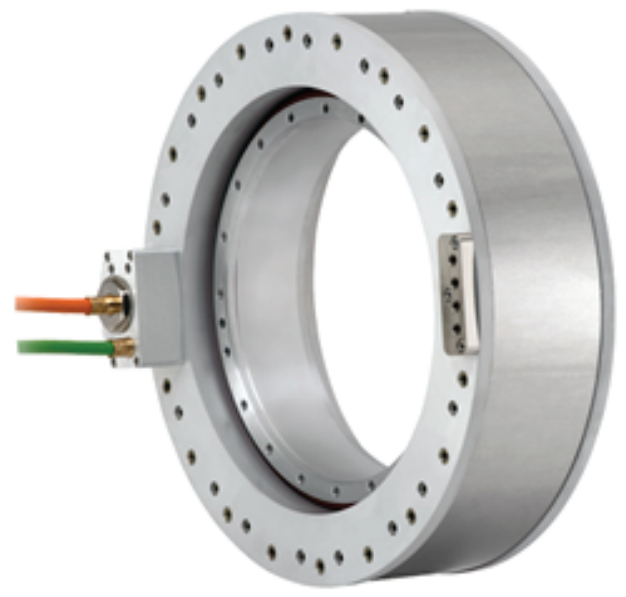

Figure 3: Example of built-in torque motor [6].

A major problem of motor spindles is the necessity of forced cooling and constant greasing of the bearing units. Cooling is required since that spindle accuracy depends on the temperature of the spindle and supports being affected by the heat release from the bearings, electric motor and the heat release during friction and cutting. Cooling is performed through air cooling or liquid cooling with water or a cooling liquid.

Motor spindles are special due to complexity of mechanical fixation of a tool or a part with stationing which reduces the processing error caused by tool setting error. To mitigate hopping and vibration during high-speed processing, it is necessary to use an accurate and expensive tool which would influence the technology cost. 
Motor spindles excel due to their relatively small dimensions and weight caused by a specific arrangement of electric motor and spindle unit. They also feature stepless rotational speed control and less dimensions/weight of the entire main drive, since there is no gear box or other mechanism [7]. This is what makes spindle operation almost silent.

\section{Results and Discussions}

Usually, decision on spindle proceeds from the main requirements for the machine tool: required rotational speed, power output and accuracy. What also matters are workplace dimensions, design complexity, application area, reparability and replaceability of spindle and electric motor. Cost is another considerable factor: belt-driven spindle is far cheaper than motor spindle. Manufacturers do not usually build complex multifunctional spindle in a simple machine tool, since the spindle cost is not far from the cost of the machine too itself. Such a spindle is used for complex machine tools where high accuracy and performance are required.

The advantages of belt-driven spindles are as follows:

1) Relatively low cost. Spindle consists of few basic components and it is cheaper than motor spindle.

2) Wide range of technical specifications. Spindle output, torque and speed depend on the motor specifications. The parameters of the main drive can be changed by selecting another electric motor or transmission ratio.

3) High output and torque. Electric motor is located outside of the spindle. Therefore, a motor of a bigger diameter can be used to ensure higher torque and output.

4) Option of quick replacement of electric motor without disassembling the machine tool.

The disadvantages of belt-driven spindles are as follows:

1) Limited maximal speed. High rotational speed provokes belt stretching which limits torque transfer. V-belts prevent this problem; however, high speeds cause inadmissible vibration level.

2) Belt gear reduces bearing load capacity. With higher outputs and spindle speeds, the required belt tension and bearing load grow thus exhausting the load capacity of the bearings;

The advantages of motor spindles are as follows: 
1) Motor spindles do not need external electric motor to ensure torque and output; therefore, they need smaller working area;

2) Electric motor is a component of spindle shaft and spindle casing; it allows rotation at higher speeds without extra limitations from belts and gears;

3) Using high-accuracy bearings improve accuracy;

4) Due to fewer units, the main drive functions quicker and with lower vibration than in a standard belt-driven spindle;

The disadvantages of motor spindles are as follows:

1) The position of spindle shaft is determined by a set of high-accuracy bearings which need constant greasing and cooling to keep operation accurate.

2) Complex maintenance because of a motor built in the shaft. Motor spindle cannot be immediately replaced or repair.

To compare options of the main drive, we calculated variants of upgrade (replacement) of the main drive in the 16M30F3 machine tool [8]. The findings are given in Table 1.

The maximal torque is observed in built-in torque motor, but the rotational speed is too low. Since the machine tool is designed for turning process, a drive with such rotational speed would not be sufficient. However, this drive type can be useful for another machine tool, with lower rotational speeds at high torque.

Belt/gear drive and motor spindle have the most suitable parameters for upgrade. Belt/gear drive has a high torque and the highest installed output power while the torque of motor spindle is slightly lower and its output is lower than that of the belt/gear drive. Rated rotational speed (up to which the electric motor reaches the rate torque) is higher for Variant 2; it allows wider processing conditions.

Proceeding from the above, we come to the following conclusion. In general, Variants 2 and 4 are approximately equal and suitable for upgrade of the observed machine tool.

\section{Conclusion}

Motor spindle has more advantages than standard drive, but it is way more expensive and its repair is more difficult. Hence, this spindle type is only applicable to machine tools with high standards of quality and performance. Belt-driven spindle is special for easy repair and a wide range of technical specifications: one can choose multiple motor 
TABLE 1: Variants of the main drive for «16M30F3» machine tool

\begin{tabular}{l|c} 
Variant \# & 1 \\
Drive Type & $\begin{array}{c}\text { Initial Drive (belt } \\
\text { and 2-step gear } \\
\text { box) }\end{array}$ \\
\hline $\begin{array}{l}\text { Speed control } \\
\text { Stepless }\end{array}$ \\
$\begin{array}{l}\text { Electric Motor } \\
\text { Type }\end{array}$ & MP160L \\
$\begin{array}{l}\text { Max. Torque on } \\
\text { Spindle, N.m }\end{array}$ \\
$\begin{array}{l}\text { Output Power, kW } \\
\text { Rated Rotational } \\
\text { Speed of Spindle, } \\
\text { rpm }\end{array}$ & 2290.0 \\
$\begin{array}{l}\text { Max. Rotational } \\
\text { Speed of Spindle, } \\
\text { rpm }\end{array}$ & 30.0 \\
\hline
\end{tabular}

2
$\begin{gathered}\text { Belt/gear drive } \\ (\mathrm{i}=2)\end{gathered}$
Stepless
$1 \mathrm{PH} 8228$
2630.0
58.0
400
2250

\begin{tabular}{|c|}
\hline \\
Built-in torque \\
electric motor \\
Stepless \\
1FW6190 \\
\hline 3960.0 \\
\hline 36.3 \\
\hline 96 \\
\hline
\end{tabular}

\begin{tabular}{|c|c|}
\hline 4 \\
\hline Motor spindle \\
\hline Stepless \\
\hline ISM 102 plus \\
\hline 2200 \\
\hline 52 \\
\hline 225 \\
\hline 2500
\end{tabular}

variants for one drive; again, it is much cheaper than motor spindle. However, final decision on spindle should concern the main requirements for the machine tool, workplace dimensions, application of the machine tool and, possibly, financial restrictions.

Further development of this research supposes analysis of energy consumption by different variants of the main drive with account of the real load profile of the drive at work. In most cases, the electric motor of the main drive runs under rated load (with rated efficiency) for a relatively short time. Therefore, it would be reasonable to find relative operation time in typical modes, estimate load factor of the electric motor, and efficiency under obtained load factors; then find energy consumption in the real load cycle (e.g., in making a specific part). Such research should give new information for better choice of a certain variant of drive with minimal energy consumption.

\section{References}

[1] V.S. Starodubov. Mechatronic drives in CNC machine tools. Izvestia vuzov. Mashinostroenie [News of higher educational institutions. Engineering], no. 5, 2014. pp. 72-77. DOI: 10.18698/0536-1044-2014-5-72-79

[2] Neugebauer R., Denkena B., Wegener K. Mechatronic Systems for Machine Tools. CIRP Annals - Manufacturing Technology, 2007, vol. 56, no. 2, pp. 657-680.

[3] Abele E., Altintas Y., Brecher C. Machine tool spindle units. CIRP Annals Manufacturing Technology, 2010, vol. 59, no. 59, pp. 781-802. 
[4] QUASER HX [Electronic resource] - Mode of access: http://www.stankopres.ru/ Page293.html (accessed 25.11.2019).

[5] High speed cutting [Electronic resource] - Mode of access: http://www.mashportal. ru/Portals/O/Tehn_Metod/manufacturing/HSC_01.gif (accessed 25.11.2019).

[6] Technical information 1FW6290-OWB20-2PB2 [Electronic resource] - Mode of access: http://siemens-ca01.ru/products/Siemens-1FW6290-OWB20-2PB2/ (accessed 25.11.2019).

[7] Poduraev lu.V. Ot mekhaniki k mekhatronike: vedushchaia tendentsiia razvitiia sovremennykh proizvodstvennykh mashin [From mechanics to mechatronics: leading the development trend of modern production machines]. Privodnaia tekhnika [Drive Technology]. 2003, no. 4, pp. 16-20.

[8] Technical information 16M30F3 [Electronic resource] - Mode of access: http://stankikatalog.ru/sprav_16m30f3.htm (accessed 25.11.2019). 